\title{
DOI: 10.7596/taksad.v10i1.3012
}

Citation: Kürtül, İ., Kapağan, E., Kundakçı, M., \& Bacaklı, Y. (2021). Türkiye'nin Uluslararası Öğrenci Stratejisi: Mevcut Durum Analizi ve Sorunların Çözümüne Yönelik Öneriler. Journal of History Culture and Art Research, 10(1), 113-131. doi: http://dx.doi.org/10.7596/taksad.v10i1.3012

\section{Türkiye'nin Uluslararası Öğrenci Stratejisi: Mevcut Durum Analizi ve Sorunların Çözümüne Yönelik Öneriler}

\author{
İbrahim Kürtül ${ }^{1}$, Enver Kapağan², \\ Mustafa Kundakç ${ }^{3}$, Yılmaz Bacaklı ${ }^{4}$
}

Öz

Bugün için dünyada hem bireyler hem toplumlar hem de devlet organizasyonları için en büyük güç kaynağı bilgidir. Bu sebeple bilgi bireysel ve toplumsal hayatın tüm dinamiklerini etkileyecek bir mahiyet kazanmaktadır. Dahası bilginin etki alanının hiçbir sınırının bulunmayışı da güç ve etkinlik sahasını genişletmek isteyen devletler için oldukça elverişlidir. Devletler bu derin ve geniş etki alanı sebebiyle bilginin keşfedilmesine, üretilmesine ciddi kaynaklar ayırmaktadır. Stratejik bir güç haline gelen bilgiye sahip olmanın yanı sıra onun pazarlanabiliyor olmasının da yapılan bu yatırımları olumlu etkilediği söylenebilir.

Yükseköğretim kurumları nitelikli bilginin işlendiği ve aktarıldığı yerlerdir. Bu sebeple nitelikli bilgiye ulaşmak ancak uygun şartlarda bu hizmeti veren yükseköğretim kurumlarında eğitim almakla mümkündür. Bilginin bugün insan ve toplumlar bakımından temel bir ihtiyaca dönüşmesi yükseköğrenim taleplerini de önemli ölçüde arttırmaktadır. Yükseköğretim kurumlarını yaptıkları yatırımlarla geliştiren ülkelerde bu kurumlara yönelik talepler sadece ülkelerin kendi vatandaşlarından değil, ülkelerinde çeşitli sebeplerle nitelikli bilgiye ulaşamayan uluslararası öğrenciler tarafından da her geçen gün artmaktadır. Bu anlamda Türkiye de yükseköğretimde ciddi bir cazibe merkezi haline gelmektedir. Türkiye'nin yükseköğretim kurumlarına yönelik uluslararası öğrenci taleplerini istenilen ölçüde karşılayabilmek için yakın zamanda ortaya koyduğu stratejinin uygulama alanında da karşılığını bulması oldukça önemlidir.

Bu çalışma Türkiye'nin yükseköğretimin uluslararasılaşması amacına dönük gerçekleştirdiği strateji ve uygulama da karşılaştığı problemleri yapılan çalışmalar, alanda yapılan gözlem ve değerlendirmeler yoluyla bugün ve gelecek ekseninde anlamaya dönük bir çabanın ürünüdür. Çalışmayla amaçlanan hem mevcut durumun bir değerlendirmesini yapmak hem de geleceğe dönük strateji ve pratik arasındaki farklardan kaynaklı sorunların çözümü için önerilerde bulunmaktadır. Çok dinamik bir biçimde gelişen yükseköğretim alanında uluslararası öğrenci hareketliliğinde belirleyici ülkelerden biri olabilmek için sürekli bir alan değerlendirmesi yapmanın, ilgili sorun alanlarına yönelik hızlı kararlar almanın ve alınan kararlarının uygulamalarının da sıkı bir şekilde takip etmenin gerekliliği açıktır.

Anahtar Kelimeler: Türkiye, Yükseköğretim, Eğitim politikası, Uluslararası Öğrenciler, Uluslararası öğrencilerin sorunları.

\footnotetext{
${ }^{1}$ Prof. Dr., Bolu Abant İzzet Baysal Üniversitesi. Orcid: 0000-0001-6269-4050 E-mail: ibrahimkurtul@ibu.edu.tr

${ }^{2}$ Doç. Dr., Bolu Abant İzzet Baysal Üniversitesi. Orcid: 0000-0003-4647-1863 E-mail: enverkapan@hotmail.com

3 Doç. Dr., Bolu Abant İzzet Baysal Üniversitesi. Orcid: 0000-0001-6092-4043

E-mail: mustafakundakci46@yaani.com
}

4 Öğr. Gör., Bolu Abant İzzet Baysal Üniversitesi. Orcid: 0000-0001-6128-5482

E-mail: yilmazbacakli@yaani.com.tr 


\title{
International Student Strategy of Turkey: Analysis of The Present Situation and Suggestions for The Solutions of The Problems
}

\begin{abstract}
Since knowledge today is the most powerful core source for individuals, society and states, it is becoming an essential leverage that affects profoundly the dynamics of all parties. For this reason, information gains a nature that will affect all dynamics of individual and social life. Moreover, the fact that there is no boundary for knowledge is very convenient for states that want to expand their power and efficiency. Due to that, they allocate a huge number of resources on producing knowledge. Commercializing the strategic knowledge is also an affirmative determinant for this allocation.

Higher education institutions are places where qualified information is processed and transferred. For this reason, it is only possible to reach qualified information by receiving education in higher education institutions that provide this service under appropriate conditions. The transformation of knowledge into a basic need for people and societies today significantly increases the demands for higher education. In countries that develop higher education institutions with their investments, the demands for these institutions are increasing day by day not only by the citizens of the countries but also by international students who cannot access qualified information in their countries for various reasons. In this sense, Turkey has become a centre of attraction in higher education seriously. It is vital for Turkey to successfully implement perpetually the Internationalization Strategy Document in Higher Education to meet fast increasing international student demands.

This paper makes an effort to review the current situation of the internationalization strategy of higher education in Turkey, summarize its implementation, emphasize problems encountered, and propose very essential suggestions for the solutions of these problems. It will surely help Turkey's effort to reach its target on the internationalization strategy of higher education, and to become an important centre of attraction for both international students and academic staffs. As suggested in this paper, this aim is acquired only under the condition of identifying problems, making decisions very fast for the solutions, and prosecuting the implementation of the decisions continuously.
\end{abstract}

Keywords: Turkey, Higher Education, Education politics, International Students, International students' Problems.

\section{GíRiş}

Küreselleşmenin doğal bir sonucu olarak gelişmiş ülkelerin tekelinde yürüyen yükseköğretim alanındaki uluslararası öğrenci ve öğretim elemanı hareketliliği, son yıllarda gelişmekte olan ülkelerin de piyasaya girmesiyle önemli bir rekabet alanına dönüşmüştür. Dünya genelindeki öğrenci hareketliliğine bakıldığında; 1970 'li yıllarda yaklaşık 800 bin olan uluslararası öğrenci sayısının 2012 yılında 4,5 milyona ulaştığı görülmektedir. Birleşmiş Milletler Eğitim, Bilim ve Kültür Örgütünün (UNESCO) yayınladığı 2018 yılı verileri, dünyada öğrenim amacıyla başka bir ülkede bulunan öğrencilerin yaklaşık 5 milyon 500 bininin Amerika Birleşik Devletleri'ndeki yükseköğretim kurumlarında öğrenim gördüğünü ortaya koymaktadır (UNESCO, 2018). Aynı kaynak, bu ülkeyi sırasıyla 450 bin öğrenci ile İngiltere'nin, 440 bin öğrenci ile Avustralya'nın izlediğini belirtmektedir. Yine bu kaynaktan alınan verilere göre Türkiye 2018 yılında 125 bin uluslararası öğrenci sayısı ile yükseköğretimde dünyada en çok uluslararası öğrenciye sahip 10'uncu ülke konumuna gelmiştir. Türkiye bu rekabet ortamında, özellikle 2010 yılından sonra üniversitelere tanınan esneklikle birlikte her geçen yıl daha çok uluslararası öğrencinin dikkatini çekmektedir (Çetinsaya, 2014: 152). Uluslararası öğrenci konusunda yapılan projeksiyonlar, dünya genelinde rakamın 2022 yılında 8 milyona çıkmasını öngörmektedir. 
Türkiye'nin son yıllarda uygulamaya koyduğu uluslararası öğrenci stratejisi ile çok kısa bir sürede yakaladığı mevcut başarı, bu alanda yükselişini sürdürerek söz sahibi bir ülke konumuna geleceğinin işaretidir. Türkiye'ye gelen uluslararası öğrenci sayısının 2019 yılında 150 bini, 2020 yılında ise 200 bini geçmesi bu öngörüyü desteklemektedir. Bu rakamların 2021 yılında Covid-2019 pandemisine rağmen YÖK'ün ve üniversitelerin aldığı kararlar, tanıtım faaliyetleri ve sanal fuarlar ile 220 bini geçmesi öngörülmektedir (YÖK, 2020). Türkiye' de öğrenim gören uluslararası öğrenci sayısının 2000 'li yılların hemen başında sadece 15 binlerde iken, son birkaç yıldaki büyük sıçrama ile hedef olarak 300 bin rakamının belirlenmesi, Türkiye'ye ve yükseköğretim sistemine özellikle “Gönül Coğrafyasından" olan ilgiyi çok daha fazla görünür kılmaktadır.

Türkiye yukarıda belirtilen rakamlara ulaşma noktasında, son yıllarda diğer gelişmekte olan ülkeler gibi yükseköğretimde uluslararasılaşma konusunda yeni stratejiler belirleyerek bir yol haritası hazırlamıştır. Pek çok açıdan olumlu sonuçları bulunan uluslararası öğrenci hareketliliğin sürekliliği, uluslararası öğrencilerin taleplerini karşılamakla mümkündür. Uluslararası öğrenciyi kendi ülkesi yerine bir başka ülkeye yönlendiren görece kaliteli ve ekonomik eğitim, uygun burs imkânları, kültürel ve dini bakımdan yakınlık gibi beklentilerin (Özoğlu ve ark., 2012: 89-90) istenilen ölçüde karşılanamaması durumunda uluslararası öğrenci hareketliliğinin sürdürülebilir olması mümkün değildir.

Yükseköğretim Kurulu uluslararası öğrenci hareketliliğinde Türkiye'nin kalıcı bir aktör olmasını sağlamak amacıyla "Yükseköğretimin niteliğini evrensel standartlara çıkararak yükseköğretim alanında uluslararası bir cazibe merkezi olmak" vizyonu çerçevesinde; 10. Kalkınma Planı ve Hükümet Programları doğrultusunda Yükseköğretimde Uluslararasılaşma Strateji Belgesi (2018-2022)'ni oluşturmuştur (YÖK, 2017). Bu belge kapsamında belirlenen üç temadan birisi olan Yükseköğretime erişim ile uluslararası öğrenci ve öğretim elemanlarının yükseköğretim kurumlarına daha kolay ulaşımını sağlayacak politikaların geliştirilmesi amaçlanmıştır. Bu politikalar ile Türkiye'nin yükseköğretim alanında bir çekim merkezi haline gelmesi ve uluslararasılaşmada kurumsal kapasitenin artması strateji olarak belirlenmiştir. Yükseköğretim Kurulu ilgili politikalar ve stratejilere ulaşmada çok geniş bir hedef planlamasını hayata geçirmiştir. Bu hedefler arasında; nitelikli uluslararası öğrenci ve öğretim elemanı sayısının artırılması, konu ile ilgili pilot devlet üniversitelerinin belirlenerek desteklenmesi, farklı dillerde öğretim programların sayısının çoğaltılması, hedef ülkeler seçimi, uluslararası öğrenciler için ayrılan barınma kapasitesinin artırılması ve burs imkânlarının çeşitlendirilmesi gibi başlıklar ön plana çıkmaktadır.

Türkiye Yükseköğretim Sisteminin uluslararası öğrenciler ve akademisyenler için bir çekim merkezi olarak devam etmesi için, yukarıda belirtilen Strateji Belgesinin uygulanması hayati önem arz etmektedir. Bu açıdan yükseköğretim kurumlarının; çeşitlendirilmesi, farklı misyonlar yüklenerek hesap verebilirlik ilkesi çerçevesinde potansiyellerinin ve kalitelerinin artırılması ve performans odaklı çalışarak rekabetçi bir yapıya kavuşturulmaları gerekmektedir. Türkiye'deki tüm üniversitelerin Yükseköğretim Kurulunun koordinasyonunda bu niteliklerin sağlanmasına odaklanmaları elzemdir.

Diğer taraftan, sürecin tarafları olan diğer kamu kurum ve kuruluşları, barınma sağlayan özel ve tüzel kişilikler, öğrenciler ve esnaf olmak üzere toplum, bu stratejinin farkında olmak durumundadır. Bu makale, Türkiye'nin öncelediği stratejilerden birisi olan Üniversitede Uluslararasılaşma Stratejisi kapsamında süreç içerisinde uygulamalarda dikkati çeken sorun alanları ve bu alanlarla ilgili ileriye dönük çözüm önerileri üzerine bir değerlendirme yapmayı amaçlamaktadır.

\section{MEVCUT SORUNLAR}

Türkiye, son yıllarda çok farklı coğrafyalardan oldukça yoğun bir biçimde uluslararası öğrenci ağırlamaktadır. Türkiye'deki uluslararası öğrenci çeşitliliği arttıkça beklentilerin çeşitliliği de 
artmaktadır. Bugün için talep konjonktürel olarak sürekli bir biçimde artmakla birlikte, hareketliliğin sürmesi ve kalıcı hale gelmesi için ortaya çıkan sorunlu alanları tespit etmek ve hemen çözüme kavuşturmak gereklidir. Türkiye'deki uluslararası öğrenci hareketliliğinde sorunların ortaya çıkmasında temel sebepler; beklentileri karşılayacak imkânlara erişimde yaşanan teknik sorunlar, meseleye sadece tek yönlü bakmanın ortaya çıkardığı olumsuz sonuçlar ve alanla ilgili tarafların yeterince profesyonel bir tanıtım ve uyumlanma hizmeti verememesi şeklinde özetlenebilir.

Uluslararası öğrenci sorunları ortaya çıktıkları ve etkiledikleri alanlardan hareketle sınıflandırıldığında üç temel başıı ön plana çıkmaktadır.

\subsection{Bürokratik Sorunlar}

Incelenen Bürokratik sorunlar, uluslararası öğrencinin Türkiye'de öğrenim almaya karar verdiği kayıt öncesi süreçle başlamaktadır. Kaydının gerçekleşmesi ve sonrasındaki öğrenim sürecinin bitimine kadar da karşılaşılması olası idari sorunlar bu başlık altında değerlendirilebilir.

\subsubsection{Kayıt Öncesi Başvuru Kabul ve Vize Dönemi}

Uluslararası öğrenci için bürokratik sorunlar başvuru süreciyle birlikte başlamaktadır. Bu aşamadaki sorunlar pek çoğu bilgi eksikliğinden kaynaklanmaktadır. Başvuru sürecinde muhatap bulamamaktan veya buldukları muhataplar tarafından eksik ya da yanlış bilgilerle yönlendirildiklerinden şikâyet eden uluslararası öğrenciler bu sürecin hemen her aşamasında sorun yaşamaktadır (Özoğlu ve ark., 2012: 97). Başvuru ve vize sürecinde ciddi bir zaman kaybı yaşadığından yakınan uluslararası öğrencilere göre bürokrasinin en büyük sorunu yavaşlığıdır (Köylü, 2001: 139).

Siyaset, Ekonomi ve Toplum Araştırmaları Vakfı (SETA) tarafından 2012 yılında yapılan bir araştırmanın elçiliklere ilişkin mülakat bölümü, yurt dışı bürokrasisinin bakışını vermesi açısından oldukça dikkat çekicidir. O tarihte konu ile ilgili görüşleri sorulan elçilik yetkililerinin pek çoğu çağrıya ya hiç cevap vermemeyi ya da olumsuz cevap vermeyi tercih etmişlerdir. Ayrıca yine aynı çalışmada uluslararası öğrenci mülakatlarının bu ilk basamak bürokrasi konusunda verdiği bilgilerin temsilciliklerin bu olumsuz tavrını ortaya koyması da oldukça dikkat çekicidir (Özoğlu ve ark., 2012: 911). Bürokratik temsilde yaşanan olumsuzlukların temel sebebi YÖK tarafından yayınlanan Yükseköğretimde Uluslararasılaşma Strateji Belgesinde yer verilen tehdit analizleriyle de yakından ilgilidir. Bu analize göre bölgesel istikrarsızlık ve güvenliğe ilişkin olumsuz algı yükseköğretimdeki uluslararasılaşma sürecini tehdit eden durumlardır (YÖK, 2017: 52). Bu algı sadece yurt dışı bürokrasi sürecini değil, yurt içindeki bürokratik işlemleri de olumsuz etkilemektedir.

Uluslararası öğrenci hareketliliğinde en etkili basamaklardan biri olan başvuru, kabul ve vize aşamasında konu ile ilgili yetkililerin meselenin doğrudan muhatabı olmak istememeleri neticesinde Türkiye'deki eğitim imkânları yurt dışında yeterince tanıtılamamakta ve en başında söylenilen bilgi eksikliği veya kirliliği ortaya çıkmaktadır. Yine bu tavır sebebiyle uluslararası öğrenci varlığı konusundaki ülke stratejisi sistemli ve istikrarlı bir biçimde yürütülememektedir.

Uluslararası öğrenci hareketliliğinin bu ilk devresindeki en önemli sorun başlıklarından biri de öğrenci kabulüdür. 2010 yılına kadar uluslararası öğrenci kabulü için yapılan merkezi sınavın kaldırılması ve kabul şartlarının esnetilmesi sonrasında üniversitelerin doğru öğrencinin doğru programa yerleştirilmesinden çok, yerleştirilen öğrenci sayısına odaklandıkları bir dönem başlamıştır. Üniversitelerin inisiyatiflerinde yürütülen bu dönemde uluslararası öğrenci konusunda nicel anlamda olumlu bir artış yaşansa da nitel anlamda benzer bir kazanımın gerçekleştiğini söylemek bugün için oldukça zordur. Çünkü doğru öğrencinin doğru programla eşleşebilmesi için birçok ülkeyi gezmek, 
fuarlara katılmak, muhatap ülkelerde ciddi organizasyonlar gerçekleştirmek gibi külfetli çalışmalara intiyaç duyulması kabul sürecinin temel problemlerinden biridir. Ciddi anlamda yetişmiş insan kaynağına ve üniversitenin kurumsal kimliğini aşan bir organizasyon yeteneğine ihtiyaç duyan bu tür bir kabul sürecini sürekli bir biçimde uygulamak oldukça zordur.

Türkiye'de üniversiteler uluslararası öğrenci kabulünde; daha çok diploma puanını, uluslararası sınav sonuçlarını, kaynak ülkenin kendi merkezi sınav sonuçlarını, Türkiye'deki diğer üniversitelerin gerçekleştirdiği YÖS (Yabancı Öğrenci Sınavı) sonuçlarını veya kendi düzenlediği YÖS sonuçlarını esas almaktadır. Üniversiteler uluslararası öğrenci kabulünde bu kriterlerden sadece birini esas alabildiği gibi kabul sürecini takvimlere bölerek birden fazla kriter de uygulayabilmektedir. Öğrencinin kabul süreçlerinde kullanılan kriterlerin her biri birtakım avantajlarla birlikte ciddi sorunları da beraberinde getirmektedir.

Kabul süreçlerinde diploma notu kullanılması üniversitelerin en yaygın olarak tercih ettiği yöntemdir. Fakat ülkelere göre değişen eğitim standartları ve ölçme ve değerlendirme süreçleri dikkate alınmadığı için diploma notları aynı olan farklı ülkelerden iki öğrencinin programdaki başarısının aynı olmayacağı açıktır. Dahası üniversitelerin kabul süreçlerindeki ülke kontenjanının da etkisiyle zorunlu olarak çeşitlenen uluslararası öğrencilerin bu fark sebebiyle aynı programda öğrenim görmesi oldukça sorunludur. Yine hangi diploma notunun hangi programla eşleştirileceği hususu da net değildir. Özellikle aracı şirketler ve üniversiteler arasındaki protokollerde diploma notunun esas alınması durumunda genellikle daha çok ikili ilişkilerin yönlendirdiği ve hakkaniyetin gözetilmediği bir kabul süreci işlemektedir. Bu protokoller kendilerine kabul sürecinin bütününden imtiyazlı bir kontenjan tahsis edildiği için kendisi dışındaki kısmını da olumsuz olarak etkilemekte, adalet duygusuna zarar vermektedir. İlave olarak kimi ülkelerde üretilmiş diplomaların bulunması ve bu belgelerin gerçek olup olmadıklarının teyidinin neredeyse imkânsız olması da bir başka sorundur.

Kaynak ülkenin merkezi yükseköğretime giriş sınavıyla ilgili olarak diploma notlarına benzer bir durum söz konusudur. Sınavların ne kadar sağlıklı şartlarda yapııdığı, soruların ölçmeye ne kadar uygun ve değerlendirmenin ne kadar gerçekçi olduğu konuları tümüyle tartışmaya açıktır. Belgenin gerçekliğinin teyidi diplomalarda olduğu gibi bu sınavlarda da oldukça zordur. Ayrıca bu tür sınavların uluslararası tanınırlığının da bulunmaması bu esasa bağlı olarak yürütülen kabul süreçlerinin sağlıklı sonuçlar vermemesine sebep olmaktadır.

Bu kriterler içerisinde doğru öğrenciyi doğru programa kabul etmek için öne çıkan en sağlıkı sistem YÖS uygulamasıdır. Diğer taraftan bu yöntemin uygulanmasında ciddi bir enerji kaybı ve kaynak israfı söz konusu olabilmektedir. Her üniversitenin kendi sınavını yapmak yönündeki tutumu Maarif, MEB, Diyanet, YTB, TiKA gibi paydaş kurumları son derece yormakta, meşgul etmekte ve beraberinde birtakım sorunlara yol açmaktadır. Bu uygulamanın bir başka sorunu da sınavların aynı amaca dönük hazırlanmasına rağmen sonuçlarının birbirinden çok farklı çıkmasıdır. Örneğin bir öğrenci, A üniversitesinin YÖS sınavından 70-80 alırken, B üniversitesinin YÖS sınavından 10-20 alabilmektedir. Bu da YÖS uygulamalarının geçerliliğini, güvenirliğini ve iyi niyetini sorgulamaya yol açmaktadır.

Bugün için kabul sürecinde yaşanan en büyük sorun birtakım eğitim danışmanı özel "şirketlerin" ortaya çıkardığı sorunlardır. Resmi ve gayri resmi olarak çalışan bu şirketlerin üniversite ile öğrenciyi buluşturma hizmetinin çok ötesinde parayla program satın alınmasına aracılık ettikleri, uygulanan tüm kriterlerden bağımsız imtiyazıı bir muamele gördükleri, sahte diploma düzenleyerek kurumları dolandırdıkları, sahte kabul belgesi hazırlayarak öğrencileri istismar ettikleri gibi iddialar ve yaşanmış ve şikâyete konu olmuş örnekler söz konusudur. Üniversitelerin, uluslararası öğrencilere ulaşmasına aracılık etmesi ve öğrenciye danışmanlık hizmeti vermesi amacıyla protokol imzaladığı bu teşekküllerin; ikili ilişkilerini kullanarak Tıp fakültesi gibi çok rağbet gören programlara öğrenci 
kaydettikleri, tamamen yasal surette yerleştirdikleri öğrencilerden yüksek miktarda ücretler alarak bu ücretlerin bir kısmını ikili ilişkilerinin devamını sağlamak adına üniversitelere bağış, hediye ve başvuru ücreti gibi ödeme türlerinde aktardıkları yaygın olarak dillendirilmektedir. Kabul sürecinin sağlıklı işlemesini engelleyen ve bu süreci kendileri ya da grupları adına bir çıkar sağlama fırsatı olarak gören bu yapılanmaların çeşitli kamu kurumlarından, bürokrasiden ve siyasetten güçlü referanslarla üniversite yönetimine baskı uyguladığı iddiaları da bugünün önemli sorunları arasındadır.

\subsubsection{Kayıt Dönemi}

Başvuru, kabul ve vize sürecini tamamlayan uluslararası öğrenci için ikinci bürokratik süreç kayıt dönemidir. Öğrencinin kayıt süreci sadece eğitim alacağı üniversiteye kabulünü içermez. Öğrencinin bu kabule bağlı olarak banka, ikamet ve sağlık sigortası gibi işlemleri de belirli bir sürede yaptırması gerekmektedir. Birden farklı kurumun işbirliğini gerektiren bu sürecin ciddi bir koordinasyonla götürülmesine ihtiyaç vardır (Özoğlu ve ark., 2012, 134).

Kayıt döneminde öğrencilerin karşılaştığı sorunlar bir önceki döneme benzer şekilde muhatap bulamama, doğru bilgiye erişememe ve yavaşlık olarak özetlenebilir. Üniversitelerin uluslararası öğrencilerin kayıt sürecini kolaylaştıracak, bu süreç konusunda deneyimli, diğer iş ve işlemlere de hâkim personellerinin bulunmamasının yanı sıra öğrencilere karşı önyargısız, asgari nezaket kuralları çerçevesinde hareket eden memurların seçilmemesi de bir başka problem alanıdır.

Bu dönemdeki en büyük problem başılılarından biri ikamet alma sürecidir. İkamet sürecini yürüten ilgili birimlerdeki çalışan sayısının iş yüküne oranı başlıca sorunlardan biridir. Dosyaların çokluğu ikamet alma sürecini uzatmakta, kimi zaman ciddi mağduriyetler oluşturmaktadır. Her ne kadar çözüm amaçlı olarak randevu sistemine geçilmiş olsa da randevular dolduğu için veya iletişim ve sistemsel sorunlar gibi başka bir sebepten randevu alamama durumunda süre ihlali yaşayan öğrenciler yükseköğretimin uluslararasılaşması stratejisi için ciddi bir risk oluşturmaktadır (Selvitopu, 2016: 127).

Kayıt sürecinde karşılaşılan diğer bir sorun genel sağılı sigortası uygulaması ile ilgilidir. Uluslararası öğrenciler ilk kayıt tarihlerinden itibaren üç ay içerisinde talepte bulunurlarsa genel sağlık sigortalısı olabilmekte aksi durumda mezun oluncaya kadar genel sağlık sigortasından faydalanamamaktadırlar (Uluslararası Öğrenci Sağlık Sigortası, 2021; Yabancılar ve Uluslararası Koruma Kanununun Uygulanmasına illişkin Yönetmelik, 2016)). Bu uygulama kayıt sürecinde sağ|ıkı bir rehberlik ve danışmanlık hizmeti alamayan öğrenciler için olumsuz sonuçlar ortaya çıkarmaktadır. Öncesinde bu sigortanın sadece maliyetini dikkate alan öğrenciler daha sonra avantajlarını fark etse de sigorta sistemine dâhil olamamaktadırlar. Yaptırdıkları hiçbir özel sağlık sigortası genel sağlık sigortası kadar kapsayıcı olmadığından ciddi bir sağlık sorununda öğrencinin eğitiminin aksaması hatta son bulması kaçınılmaz hale gelebilmektedir.

Kayıt dönemindeki en büyük sorunlardan bir başkası, en başta sayılan bilgi ve uyumlama süreci eksikliğinden kaynaklı şirketleşme temayülüdür. Eğitimin bugün için pazarlanan bir şey olduğu bir gerçektir, fakat tüm boyutlarıyla ticaretin alanına dönerek metalaşması eğitimin manevi boyutuna ciddi biçimde zarar vermektedir. Üstelik eğitim şirketlerinin bilgi eksikliğinden ya da kirliliğinden faydalanarak bu alanı bir tür sömürü aracı haline çevirmesi problemin etki alanını büyütmektedir. Öğrenci seçimine ve kayıt sürecine aracılık hizmeti veren eğitim danışmanlığı şirketlerinin bu hizmetin karşılığını alması bir problem oluşturmamaktadır. Problem, çoğu zaman hizmet bedelinin çok üzerinde alınan tutarın ilgili şirket tarafından üniversitenin eğitim bedeli olarak gösterilmesidir.

Yukarıda ifade edilen şirketleşme sürecinin bir başka yansıması da eğitim kurumlarında görülmektedir. Üniversitelerin eğitim harçlarını belirlemede belirli bir kıstas kullanmadığı, çoğunun keyfi tutarlar belirlediği izlenimi uyandıracak birbirinden çok farklı tutarlar açıklamaları, yıllık harç 
tutarlarında önceki yılları da etkileyecek şekilde afakî artırımların yapılması, harç tutarı dışında bir defalık kaydıyla tam olarak hangi hizmetin bedeli olduğu açıklanmayan yüksek tutarlı ödemelerin alınması yükseköğretimin uluslararasılaşması sürecine uzun vadede ciddi zararlar verecek uygulamalardır. Şirketlerin istismarına konu olan ve üniversitelerin birçoğunun da bilerek ya da bilmeden parçası olduğu ekonomik bakımdan olumsuzluklar içeren ve bir güven sorununa dönüşen kayıt süreci, bugün için sorun gibi algılanmıyorsa da ilerde ciddi bir sorun alanı olacağı açıktır.

Türkiye'nin yükseköğretimde belirlediği stratejilerin gereği olarak her türlü burs imkânı ve ekonomik kolaylıkla desteklediği yükseköğretimde uluslararasılaşma sürecinin altı çizilen bu iki sorun sebebiyle zarar gördüğü söylenebilir. Yükseköğretim için Türkiye'yi tercih eden uluslararası öğrenci profili de göz önünde bulundurulduğunda ekonomik olma niteliğini yitiren ve güven vermeyen bir eğitim ortamında öğrenci kabul sürekliliğini sağlamanın zorlaşacağı açıktır.

\subsubsection{Kayıt Sonrası ve Mezuniyet Dönemi}

Uluslararası öğrencilerin kayıt sonrasında ve mezuniyet sürecinde karşılaştığı bürokratik sorunların başında danışmanlık, denklik ve istihdam meselesi gelmektedir. Gerek akademik birim gerekse idari birim yöneticileri ile istenen şartlara uygun bir ilişki kurması öğrencinin danışmanının ilgisine bırakılmaktadır. Fakat öğrencilere danışman olarak verilen isimler bu işi genellikle kâğıt üzerinde yaptığından, uluslararası öğrenci dersleri dışındaki bürokratik süreçlerde çok zaman kaybetmekte ve motivasyonu ciddi bir örselenme sürecinden geçmektedir. Yönetmeliklerin farklı dillere tercüme edilmemiş olması, kolayca ulaşılabilir olmaması gibi sebeplerle idari ve akademik yönetime derdini anlatmak ve gerekenleri yapmak konusunda ya yetersiz ya da geç kalmaktadır. Uluslararası öğrenci sürecin tüm aşamalarında bu durumun mağduru olmasına rağmen kötü muamele görüp azarlanmakta ve sürekli eksiklikler, gecikmeler, yanlışlıklar için suçlanmaktadır.

Uluslararası öğrencinin kayıt sonrası sürecinde yaşadığı bir başka bürokratik sorun ise denklik meselesidir. Öğrencinin kaydını alan ve gerekli eğitimi veren üniversite, öncesinde gereken girişimleri yapmadığından kimi ülkelerin eğitim kurumlarınca tanınmadığı için öğrenci, diplomasının denklik belgesini alamamaktadır. Öğrenci durumu üniversiteye bildirmesine rağmen kendisini sadece kayıt ve eğitim süreciyle ilgili sorumlu sayan bir anlayışla çoğu üniversite idaresi bu sorunu görmezden gelmektedir. Dahası, usulüne göre yapılacak yazışma ve bilgilendirme süreçlerini iş yükü olarak görmekte ve denklik sürecindeki muhataplarının herhangi bir işleme gerek kalmaksızın kendilerini tanımalarını beklemektedir.

Kayıt sonrasındaki en büyük sorunlardan biri de yükseköğretim kurumundan mezun olan öğrencinin istihdam sürecinin takibinin yapılmamasıdır. Üniversitelerde uluslararası öğrenci mezunlarına dönük sağlıkı bir çalışma yapılmadığından stratejik önemi olan bu alanın verimliliği ciddi oranda düşmektedir. Takibi yapılmayan yetişmiş öğrencinin her nerede istihdam edilirse edilsin ülke ve kurum adına sağlayacağı katkı kaybedilmekte, öğrencinin istihdam sürecini doğru yönetememesinin maliyeti ise kaçınılmaz olarak ülke ve eğitim kurumuna kesilmektedir. Hem öğrencinin hem de öğrenciyle ilişkili tüm süreçlerin nezdinde ülke ve kurum ciddi bir imaj kaybına uğramaktadır.

\subsection{Akademik Sorunlar}

Uluslararası öğrencilerin bürokratik sorunlardan sonra başlıca problem alanı akademik sorunlardır. Bu sorun alanının içeriği eğitim sürecini ilgilendiren başlıklardan oluşmaktadır. Özellikle dil öğrenimi başta olmak üzere, öğretim elemanı, ölçme ve değerlendirme gibi başlıklar akademik sorun alanında değerlendirilecektir. 


\subsubsection{Dil (Türkçe) Hazırlık Sorunu}

Uluslararası öğrencinin yükseköğretimde tutunması ve başarılı olması ancak yeterli bir dil eğitimi alması ile mümkün olabilir. Özellikle Türkçe eğitim veren programlara kaydını yaptıran öğrencilerin karşılaştığı en büyük problem hazırlık sürecinde akademik bilgiye erişebilecek bir dil donanımı kazanamamaktır. Akademik saha için sunulan Türkçe dil hazırlık eğitiminin genel sorun başlıklarını ders öğretim araç gereçleri konusundaki yetersizlikler, öğretim programının ve elemanının yetersizliği, Türkçe hazırlık öğretiminin kaynak dil gruplarının özelliklerine ve hedef programlara göre ayrılmamış olması, Türkçe hazırlık öğretimi veren kurumlar arasındaki koordinasyon eksikliği ve belki de en önemlisi bu konuda bir belirlenmiş bir devlet politikasının bulunmayışı şeklinde sıralanabilir (Er ve ark., 2012: 59-60).

Uluslararası öğrencileri akademik eğitime hazır hale getirmesi beklenen Türkçe hazırlık merkezlerinde yaşanan başlıca sorun hedef kitlenin ihtiyacından bağımsız bir dil öğretim sürecinin benimsemiş olmasıdır. Dört temel dil becerisi arasından akademi için gerekeni belirlemekte zorluklar yaşayan kimi dil merkezleri, ayrıca öğrencilerin dil öğrenim süreçlerini besleyebilecek yeterli kaynağa ve öğretim elemanına da sahip değildir. Dil öğretimi konusunda özellikle yazılı ifade becerisi yerine sözlü ifadenin öncelenmesi öğrencinin sınavlarda başarısız olmasına neden olmaktadır. Konuşma ve dinleme becerisini dil merkezleri dışındaki ortamların da katkısıyla yeteri kadar geliştiren öğrenciler, derslerin temel kaynakları olan kitapları okuyup anlamada ve ölçmenin neredeyse tek aracı olan yazıı değerlendirmelerde ciddi sorunlar yaşamaktadırlar.

Dil öğretim sürecindeki sorunlar uluslararası öğrencileri çok esaslı bir tercihe mecbur bırakmaktadır. Yükseköğretime devam etme ya da ayrılma konusunda bu sürecin belirleyici etkisi vardır. Bu süreçteki eksikliklerin fark edilmesi ise ancak akademide lisans eğitim sürecinin başlamasıyla anlaşılabilmektedir. Zira öğrenci öncesinde sözlü ifade ve dinleme konusundaki becerilerini geliştirebilmesinden hareketle geçici bir iyimserlik süreci yaşamakta, lisans eğitiminin başlamasıyla birlikte kitaplar ve sınavlarla karşılaşmakta, yazılı ifade ile okuma becerisindeki eksiğini ancak o zaman fark edebilmektedir. Bu olumsuz duruma rağmen sene kaybına uğrama korkusuyla birçok uluslararası öğrenci az bir başarıya razı olarak zoraki de olsa eğitim sürecini tamamlamak için uğraşmaktadır.

\subsection{2. Öğretim Elemanı Sorunu}

Uluslararası öğrenci hareketliliğinde etkili olan temel dinamiklerden biri de kaliteli eğitim ve bu eğitim imkânını sağlayabilecek nitelikli akademik kadroların varlı̆ı̆ır (Demirhan, 2017: 552). Öezllikli bir akademik kadro yükseköğretimdeki uluslararasılaşma sürecini kendisi için de yeni kültürleri ve düşünceleri tanıma fırsatı olarak değerlendirmektedir. Buna karşılık yükseköğretimde uluslarasılaşma sürecinin temel sorun alanlarından biri yine öğretim elemanı kaynaklıdır.

Yükseköğretimde uluslararasılaşma sürecinden bağımsız olarak yaşanan bir öğretim elemanı sorunu olduğu bilinen bir gerçektir. Gerek uluslararasılaşma süreci gerek günün ihtiyaçları gerekse de genç nüfusun yoğunluğuna bağlı olarak Türkiye'de öğrenci sayısı her geçen yıl artmaktadır. Bu artışa karşıık öğretim elemanı sayısındaki artış yetersizdir. Bunun yanı sıra bütçe imkânlarının kısıtıılığı, farklı sebeplerle yaşanan yetişmiş eleman kaybı, gelişmiş ülkelerle kıyasıya rekabet içinde olmak ve üniversiteler arasındaki işbirliklerinin istenen ölçüde ve sağlıklı bir şekilde gerçekleşmemesi öğretim elemanı sorununu hem nitelik hem de nicelik olarak etkilemektedir (Selvitopu, 2016: 36).

Yükseköğretimde uluslararasılaşma sürecinde yaşanan öğretim elemanı sorununun nicelik anlamda çözülmesinin, nitelikten kaynaklı sorunların çözülmesinden daha kolay olduğu açıktır. Nitekim yükseköğretimde uluslararasılaşma stratejisi gereği farklı dillerde programlar açılması bugün için en 
temel ihtiyaçlardan biridir. Bu ihtiyaca bağlı olarak birçok üniversitede özellikle mühendislik, finans gibi alanlarda farkı ıillerde yeni programlar açılmaktadır. Fakat bu programlardaki öğretim elemanlarının programın diline hâkim olmadıklarına dönük çok sayıda uluslararası öğrencinin şikâyetçi olduğu da bir gerçektir.

Uluslararası öğrenciler için önemli bir başka sorun, kültür, inanç ve etnik özelliklerinden dolayı öğretim elemanlarından olumsuz ve ayrımcı tavır görme ihtimalidir. Bu tavrı sergileyen öğretim elemanı sayısının yükseköğretim kurumlarında oldukça az olduğu yapılan örnek araştırma çalışmalardan anlaşılmaktadır (Geçgil ve Alagöz, 2017: 283). Fakat az olması sorunun küçük olduğu anlamına gelmemektedir. SETA tarafından 2012 yılında yapılan bir araştırmaya da detayları ile yansıdığı gibi (Özoğlu ve ark., 2012: 103-104, 119) öğretim elemanının uluslararası öğrenciye karşı sergilediği olumsuz tutumla ilgili tedbir alınmaması durumunda günün sosyolojisinden kaynaklı olarak bu tavrın yaygınlık kazanması tehlikesi de bulunmaktadır.

\subsubsection{Ortak Zorunlu Dersler ve Ölçme Değerlendirme Sorunu}

Türkiye' de Yükseköğretimde ilk sınıfta iki dönem halinde verilen ve ortak zorunlu dersler olarak anılan Türk Dili, Atatürk illkeleri ve İnkılap Tarihi dersleri öğrencilerin daha önce aldıkları 12 yıllık ilk ve ortaöğretim sürecini özetleyen ve pekiştiren bir içeriğe sahiptir. Burada geçmişteki öğrenim sürecinde kazanıldığı varsayılan birçok bilgi en özet şekliyle ve çoğu yükseköğretim kurumunda uzaktan eğitim şeklinde hatırlatılmakta ve öğrencilerden sadece bu iki dönemde anlatılanlardan değil çoğu defa derslerin geçmiş müktesebatından da hareketle değerlendirmeler yapmaları beklenmektedir.

Ancak Türkiye'ye yükseköğrenim için gelen uluslararası öğrencilerin bu derslere dair bir geçmiş dönem tecrübeleri, birikimleri bulunmamaktadır. Türk Dili ile Atatürk Ilkeleri ve İnkılapları dersinden bu sebeple bir fırsat eşitsizliği ortaya çıkmaktadır. 2547 sayılı Yükseköğretim Kanunun 5. Maddesinin (ı) bendinde ortak derslerle ilgili düzenleme yapılırken yine aynı maddenin (f) bendinde "Yükseköğretimde imkân ve fırsat eşitliğini sağlayacak önlemler alııır." ifadesi yer almaktadır. Yukarıda anılan iki dersten olumsuz anlamda etkilenen uluslararası öğrenciler yabancı dil olarak verilen dil derslerinde ise kimi zaman o dili ana dil olarak kullandıkları için diğer öğrencilerin aleyhine olacak şekilde faydalanmaktadırlar. Ortak zorunlu derslerin planlanması daha çok yerli öğrencilerin durumları ve düzeyleri düşünülerek yapıldığı için de bu derslerin verilmesi ve ölçülüp değerlendirilmesinde ciddi güçlükler yaşanmakta ve sorunlar ortaya çıkmaktadır.

Yükseköğretimde yerli öğrencilerin de şikâyetçi olduğu ölçme ve değerlendirme konusunda uluslararası öğrenciler de benzer sebeplerle rahatsızdır. Özellikle öğretim elemanının ölçme ve değerlendirme sürecinde şeffaf olmadığı konusunda yoğunlaşan şikâyetler, ölçme araçlarının isabetsiz olduğu ve değerlendirmenin sübjektif bir biçimde yapıldığı şeklinde alt başlıklar da içermektedir. Ölçme konusunda birbirinden çok farklı uygulamaların görülmesi de bir başka sorundur. Öğretim elemanından eğitim süreci boyunca edindiği izlenimden hareketle öğrenci, ilgili öğretim elemanının genel tutumundan hareketle sınavının değerlendirmesinin kesinlikle ön yargı içerdiğine inanmaktadır.

\subsection{Sosyolojik Sorunlar}

Hazırlık süreci ile en az 5 beş yıl Türkiye'de yaşayan uluslararası öğrenci için sosyal ortamların önemi büyüktür. Eğitim ortamı dışında zamanını geçirdiği sosyal mekânlar ve ortamlar onun eğitimindeki başarısını direk olarak etkilemektedir. Uluslararası öğrencinin eğitim dışındaki zamanının çoğunu geçirdiği ev ya da yurtlar ile ilgili olumsuz durumlar, şehrin ve insanların kabullerine uyum sürecinin doğru yönetilememesi gibi sorunlar bu başlık altında değerlendirilecektir. 


\subsubsection{Barınma Sorunu}

Uluslararası öğrencinin yükseköğretim sürecinde karşılaştığı en önemli sorunlardan birisi barınma sorunudur. Türkiye'de henüz yükseköğretimde uluslararasılaşma stratejisine uygun olarak yapılan bir konaklama planlanmasından hem genel anlamda hem de üniversitelerin her biri anlamında söz etmek mümkün değildir. En fazla şikâyetin geldiği barınma konusunda öğrenci çoğu zaman bir başına bırakılmakta ve bu sebeple henüz eğitiminin en başında ciddi bir istismara uğramaktadır (Özoğlu ve ark., 2012: 139).

Kredi Yurtlar Kurumuna ait yurtlarda sınırlı sayıda, kontenjanın \%1'i kadar, uluslararası öğrencinin kalmasına izin verilmektedir. Bu durum öğrencileri ister istemez özel yurtlara mecbur bırakmaktadır. Devlet yurtlarının bu konuda değişik seçenekler sunamaması öğrenciler için barınmanın öncelikle ekonomik bir soruna dönüşmesine neden olmaktadır. Özel yurtlar uluslararası öğrencilerden oldukça yüksek konaklama bedelleri isterken sundukları yemek, sosyal faaliyet mekânı ve oda hizmetlerinde öğrencinin uluslararası niteliğini göz önünde bulundurmadan hareket etmektedirler. Özellikle Afrika orijinli öğrencilerin en azıyla yetinebileceği ön kabulüyle bu öğrenciler yüksek maliyet düşük hizmet anlayışıyla karşılaşmaktadır.

Diğer taraftan belli sayıda öğrencinin kiralık ev, süit oda gibi mekânlarda kalma isteği sosyal ve kültürel farklılıklar dolayısıyla yönetilmesi zor bir süreç haline gelmektedir. Öğrenciler zorlukla kiralık ev bulabilmekte, kendilerinden oldukça yüksek kira bedelleri çoğu zaman peşin istenmekte, evin eksikleri konusunda ise ev sahibine düşen yükümlülüklerden kaçınılmaktadır. Yaşadıkları sorunlarla ilgili olarak ise diğer pek çok konuda olduğu gibi ya muhatap bulmakta zorlanmakta ya da gerekli muhataplara hiç ulaşamamaktadırlar. Özellikle barınma konusunda yaşadıkları sorunlar uluslararası öğrencilerin akademik başarıları kadar sosyokültürel uyum süreçlerini de olumsuz etkilemektedir.

\subsubsection{Toplumsal Ortama Uyum Sorunu}

Yükseköğretimde uluslararasılaşma sürecinin en sıkıntılı alanlarından birisi öğrencilerin toplumsal hayata uyum sürecidir. Genel olarak öğrencilerin eğitimlerini sürdürdükleri şehrin insanına, kabullerine, inançlarına ve sivil ve resmî kurumlarına yönelik profesyonel ve planlı bir uyumlaştırma çalışması gerçekleştirilmemektedir. Öğrenciler daha önce hiç karşılaşmadıkları insanlarla, yine hiç bilmedikleri toplumsal ortamlarla çoğu zaman sıkıntılı ve karşılıkı kalıcı ön yargılara sebep olabilecek yanlış anlama ve anlaşılma tecrübeleri ile tanışmaktadır.

Toplumsal uyum sorununda uluslararası öğrencinin dil konusundaki yetersizliği, maddi sıkıntıları, kültürel farklılıkları, özlem ve yalnızlıktan kaynaklı psikolojik sorunları kadar toplumun uluslararası öğrenci konusundaki bilinçsizliğinden kaynaklı ayrımcı tutumu ve farklı sebeplerle bu öğrenciler üzerinde oluşan baskılar da oldukça etkilidir (Özoğlu ve ark., 2012: 28-33). Eğitim sürecinin özellikle ilk yıllarında ortaya çıkan uyum sorununun şiddeti, öğrencinin kendi ülkesi ile geldiği ülke arasındaki kültürel farklılıkların derinliğine göre ve öğrencinin bu farklılıklara karşı hazır bulunuşluğuna göre değişmektedir. Yükseköğretime başlama yaşının da kendisine has özellikleri dikkate alındığında hem kişisel ölçekte hem de toplumsal bağlamda bir geçiş süreci yaşayan genç öğrencilerin uyum sürecinin gerekli planlama ve bilgilendirme yapılmadığında iki taraflı olarak sıkıntılara maruz kalması kaçınılmazdır (Ercan, 2012: 12-34).

Diğer taraftan, son dönemlerde uluslararası öğrencilerin topluma dönük beklentileri üzerine az da olsa araştırma yapıımakta, bunların çözümlenmesi ile ilgili çalışmalar da gerçekleştirilmektedir. Buna karşıık toplumun uluslararası öğrenci algısının ne olduğu konusunda yapılmış nitelikli bir araştırmanın bulunmaması ciddi bir eksikliktir. Oysa toplum da bu sürecin bir parçasıdır. Onların bu konudaki 
algılarının da doğru bir şekilde yönetilmesine intiyaç vardır. Karşılıklı yanlış bilinenler ve saygı konusundaki karşııkı eksiklikler oldukça fazladır.

\section{3. ÇÖZÜM ÖNERILERI}

Toplumsal uyum sorununda uluslararası öğrencinin dil konusundaki yetersizliği, maddi sıkıntıları, kültürel farklılıkları, özlem ve yalnızlıktan kaynaklı psikolojik sorunları kadar toplumun uluslararası öğrenci konusundaki bilinçsizliğinden kaynaklı ayrımcı tutumu ve farklı sebeplerle bu öğrenciler üzerinde oluşan baskılar da oldukça etkilidir (Özoğlu ve ark., 2012: 28-33). Eğitim sürecinin özellikle ilk yıllarında ortaya çıkan uyum sorununun şiddeti, öğrencinin kendi ülkesi ile geldiği ülke arasındaki kültürel farklılıkların derinliğine göre ve öğrencinin bu farklılıklara karşı hazır bulunuşluğuna göre değişmektedir. Yükseköğretime başlama yaşının da kendisine has özellikleri dikkate alındığında hem kişisel ölçekte hem de toplumsal bağlamda bir geçiş süreci yaşayan genç öğrencilerin uyum sürecinin gerekli planlama ve bilgilendirme yapılmadığında iki taraflı olarak sıkıntılara maruz kalması kaçınılmazdır (Ercan, 2012: 12-34).

Diğer taraftan, son dönemlerde uluslararası öğrencilerin topluma dönük beklentileri üzerine az da olsa araştırma yapılmakta, bunların çözümlenmesi ile ilgili çalışmalar da gerçekleştirilmektedir. Buna karşılık toplumun uluslararası öğrenci algısının ne olduğu konusunda yapılmış nitelikli bir araştırmanın bulunmaması ciddi bir eksikliktir. Oysa toplum da bu sürecin bir parçasıdır. Onların bu konudaki algılarının da doğru bir şekilde yönetilmesine ihtiyaç vardır. Karşılıklı yanlış bilinenler ve saygı konusundaki karşııklı eksiklikler oldukça fazladır.

\subsection{Bürokratik Alandaki Sorunlara Dönük Çözüm Önerileri}

Uluslararası öğrencilerin gerek eğitim süreci başlamadan gerekse eğitim süreci başladıktan sonra mutlaka karşılaştıkları bürokratik süreçlerin yürütülme biçimi ve öğrenci hareketliliğine bakışı oldukça önemlidir. Bu sürecin doğru yönetilmesi akademik ve sosyolojik alanlardaki işleyişe olumlu yansımaktadır. Uluslararası öğrenci hareketliliğinde en önemli aşama olan bürokratik alan, yurt dışı temsilciliklerinden başlayarak üniversitelerin öğrenci işleri yetkilisine kadar uzanan tüm bürokratik süreçleri sevk ve idare edenlerden oluşmaktadır. Uluslararası öğrenci hareketliliğinde etkili ve olumlu bir stratejinin öncelikli olarak bu alandaki sorunların ortadan kaldırılması gerekmektedir.

\subsubsection{Kayıt Öncesi Başvuru ve Kabul Dönemi}

Uluslararası öğrenci hareketliliğinin ilk aşaması olan başvuru sürecinde aslında uluslararası öğrencinin öğretim görmek istediği ülke ile ilgili kesin bir karar vermemiş olma ihtimali yüksektir. Başvuru sürecinde yaşanabilecek her türden olumsuzluk öğrencinin kararını gözden geçirmesine ve farklı bir seçeneğe yönelmesine neden olabilmektedir. Bu nedenle başvuru sürecinin oldukça sade, anlaşılır ve her detayının net olması önemlidir. Bu sadeliğin ve netliğin sağlanabilmesi için başvuru süreci ciddi bir tanıtım ve danışmanlık faaliyeti ile desteklenmelidir (Özoğlu ve ark., 2012: 130-131).

Kayıt öncesi başvuru döneminde gerçekleştirilecek tanıtım hizmetlerinin esasını oluşturacak bir planlama ve koordinasyon çalışması mutlaka yapıımalıdır. Esasında yükseköğretimde uluslararasılaşma sürecinin diğer tüm sorun başıklarını bu dönemdeki yapılacak iyi bir planlama, koordinasyon ve tanıtım faaliyeti ile ortadan kaldırmak veya şiddetini yönetilebilir bir seviyeye çekmek mümkündür. Bugün için Türkiye yükseköğretimde uluslarasılaşma çalışmalarını bir devlet politikası haline getirmekle beraber, bu stratejik alanla ilgili yapılan yerleşik planlama, koordinasyon ve tanıtım faaliyetleri yeterli gözükmemektedir. 
Bu anlamda Yükseköğretim Kurulunun 2018-2022 yıllarına ilişkin Yükseköğretimde Uluslararasılaşma Strateji Belgesi başvuru ve vize sürecindeki bürokratik sorunlara dönük yerinde çözüm planları içermektedir. Strateji belgesinde yer alan öncelikle Yükseköğretim Kurulu ve pilot üniversiteler bünyesinde "Uluslararası İlişkiler Daire Başkanlığı"nın ihdası; konunun taraflarıyla bir araya gelerek ilgili mevzuatın güncel gelişmeler ve bu konudaki eğilimler ışığında yeniden yapılandırılması için tartışmalar düzenlenmesi; yükseköğretim alanı ile ilgili mevcut durumu ve gelişmeleri yurtdışındaki muhataplara iletmek amacıyla alanda yetkin bir akademisyenin "akademik müşavir" sıfatıyla, özellikle hedef ülke büyükelçiliklerinde istihdam edilmesi gibi hedeflerin Türkiye'nin uluslararası öğrenci hareketliliğine ciddi bir ivme kazandıracağı açıktır (YÖK, 2017: 66-69).

Uluslararası öğrenci hareketliliği strateji belgesinin oluşturulmasını zorunlu kılan siyasi, sosyal, ekonomik ve insani dinamiklerin farklı araştırma çalışmaları ile ortaya konulması ve devletin ilgili birimlerinin bu konuda hazırlayacağı raporların tüm taraflarca paylaşıması alanın sağlıklı bir biçimde gelişimi için önemlidir. Zira bu strateji belgesinin kâğıt üzerinde kalmaması ve işlerlik kazanması ancak bu şekilde mümkün olabilir. Uluslararası öğrenci hareketliliğinin Türkiye'ye katkıları konusunda ideolojik, ekonomik veya güvenlik kaynakı itirazı, çekincesi olan bürokratların ve memurların süreci bilerek ya da bilmeyerek engellemesinin önüne ancak bu tür çalışmalarla geçilebilir. Dış temsilciliklerdeki tanıtım eksikliği, uzun vize süreçlerinin karmaşıklığı ancak oradaki personelin yurt içinde yürütülen stratejinin bir parçası haline getirilmesi ile ortadan kaldırılabilir.

Üniversitelere kabulde uygulanan kriterlerde tüm üniversiteleri bağlayacak kriterlerin belirlenmesi gerekmektedir. Öğrenci kabulünde diploma notunun bir kriter olarak kullanılması en son tercih edilecek yöntem olmalıdır. Diploma notunun kabule esas olarak kullanılması durumunda ise başvuruların yapıldığı ülkelerin eğitim sistemi ve ölçme ve değerlendirme koşullarına ilişkin bir ön değerlendirme mutlaka yapılmalıdır.

Öğrenci kabulüne ilişkin en sağlıklı yöntem olan YÖS uygulamasının tek merkez tarafından yılda birkaç kez uygulanması ve öğrencilerin bu sınavlardan aldıkları sonuçlara göre öğrenim görecekleri üniversitelere başvurmaları sağlanmalıdır. Bu durumda sınavların daha çok kaynak ülkelerde gerçekleştirilmesi zarureti doğacaktır. Bunun içinde Türkiye'nin yurt dışındaki eğitim kurumlarının bağlı bulunduğu Maarif Vakfı, ülkenin dil ve kültür tanımını gerçekleştiren Yunus Emre Vakfı ve TíkA'nın organizasyon imkanları kullanılmalıdır. Sınavların hazırlanması ve uygulamasında, her yıl değişmekle birlikte Türkiye'de uluslararası ögrrenciler tarafından en çok tercih edilen üniversiteler de görev almalıdır. Böylelikle aracı kurumların kabul sürecini istismar etmesi de önlenir. Ayrıca sınava aracılık eden yurt dışındaki kurumların ilk elden tanınması da sağlanır.

\subsubsection{Kayıt Dönemi}

Uluslararası öğrencinin, öğrenim göreceği ülkeye giriş yaptıktan sonra, üniversiteye kayıt ve ikamet işlemleri gibi birtakım işlemleri yapması gerekmektedir. Farklı bir ülkede ilk defa bulunmanın vermiş olduğu hissiyat, yabancılık ve bilgi eksikliğine bağlı olarak öğrenciler bu süreçlerde zorlanabilmektedir. Dolayısıyla, üniversite ya da ilgili kurumlarca bu konuda koordineli bir şekilde rehberlik yapılması ve belirli bir oryantasyon programı dahilinde destek sağlanması son derece önemlidir. Danışmanlık hizmeti olarak da adlandırılabilecek kayıt dönemi destek faaliyetleri başvuru süreci ile koordineli bir biçimde yürütülmelidir.

Başvuru döneminde yer alan planlama, koordinasyon ve tanıtım olarak ifade edilen temel üç faaliyet alanı daha çok kurumsal veya bireysel inmalden kaynaklanan sebeplerle sorunlar yaşarken kayıt döneminin en temel faaliyet alanı olan danışmanlık hizmetlerinde ihmale ek olarak bir de istismarın varlığı dikkati çekmektedir. Diğer üç başıktaki zaaftan istifade eden kimi şahıslar, gruplar, 
çevreler veya ekonomik teşekküller tarafından istismar edilen danışmanlık hizmetlerinin acilen bir düzene kavuşturulması gerekmektedir. Danışmanlık konusunda devleti temsil eden bürokrasinin yetersiz ya da isteksiz olması öğrenci hareketliliğinin insan kaçakçılığı, adaletsizlik veya bir çeşit güvenlik sorunu olarak algılanmasına yol açabilecek sorunlara yol açmaktadır. Ayrıca danışmanlık hizmeti karşılığı alınan yüksek tutarlı bedeller kötü niyetli kimse, grup, çevre yahut kuruluşların zarar verici faaliyetlerini gerçekleştirmek üzere kullanacakları finansın kaynağı olarak kullanılabilmektedir.

Valilikler, belediyeler ve rektörlükler arasında ciddi bir uyuma ihtiyaç duyan kayıt döneminin iyi yönetilmiş bir başvuru sürecinden olumlu olarak etkileneceği de açıktır. Kayıt sürecinin mümkün olabildiği ölçüde tek merkezden yürütülmesi, öğrencinin muhatap kurum ve kişi sayısının olabildiğince sadeleştirilip azaltılması verimi artıracaktır. Öğrencinin yükseköğretime kaydıyla birlikte kazanması kuvvetle muhtemel olan ikamet sürecinin de gelişen teknolojik imkânlara bağlı olarak gerekli evrakların kayıt evraklarına eklenerek alınmasıyla otomatik olarak gerçekleştirilmesi gerekmektedir. Bugün için her üniversitede yaygın olarak bulunmayan, bulunsa da aktif olarak çalışmayan Uluslararası Öğrenci Koordinatörlükleri kayıt sürecinin ikamet ve sigorta başlıklarını da içerek biçimde çalışmalıdır. Her ne kadar sürecin gerisinde farklı kurumlar da kendilerine düşen iş ve işlemi yürütse de bilgi paylaşımı yoluyla öğrencinin süreçle ilgili tek muhatabının bu koordinatörlükler olması kayıt sürecinin ve sonrasının kurum ve öğrenci açısından daha sağııkı yürütülmesini sağlayacaktır.

Kayıt döneminde üniversiteler dışındaki bürokratik işlemlerin il Göç İdarelerince yürütülmesi simgesel anlamda uluslararası öğrencinin ülkedeki varlığını sorunlu hale getirmektedir. Öğrencilerim mülteci ya da göçmen olmadığı açıktır. İşlemleri bu birimlerce yürütülen öğrencilerin Türkiye'de bulunma amacı konusunda da bu sebeple karışıklık yaşanmaktadır. Bu sebeple uluslararası öğrencilerin bürokratik işlemlerini yürütecek yeni bir birimin oluşturulması gerekmektedir.

Kayda esas olarak gönderilen kabul mektuplarında öğrenci kabul şartları ve ilgili öğrencinin bu kabul koşulları konusundaki yeterliliklerine atıf yapılması kayıt sürecini de kolaylaştıracaktır. Buna karşılık bugün yapıldığı gibi önce öğrenciyi kabul etmek daha sonra ona uygun bir program arayışına girmek hem kayıt sürecindeki yükü artırmakta hem de ciddi bir kaynak ve zaman israfına sebep olmaktadır. Kayıt sürecinin hiçbir kriter dikkate alınmaksızın gerçekleştirilmesi sürecin ilerleyen zamanlarda motivasyon kaybı, güven ve adalet duygusunun sarsılması gibi sebeplere bağlı olarak aksamasına hatta kalıcı hasarlar almasına sebep olabilmektedir. Bu sebeple kabuller ve kayıtlar mutlak surette tüm yükseköğretim kurumlarını bağlayacak kriterlere bağlanmalıdır. Önemli olanın uluslararası öğrencinin istatistik olarak artması olmadığı için kurumsal değerlendirmelerin daha çok nitelik çıktıları üzerinden yapılması zorunludur. Böylelikle sadece rakamların artışına odaklanan bir kayıt süreci yerine doğru programın doğru öğrenciyle eşleştirildiği bir kayıt süreci yaygınlık kazanacaktır.

Harç tutarlarının tespitinde herhangi bir kriterin kullanılmaması ve tam olarak niçin alındığı belli olmayan bir defalık ödemeler gibi sorunlar ise kayıt sürecinde yaşanan ama yükseköğretimde uluslararasılaşma stratejisinin tüm aşamalarına uzun vadede büyük zararlar verebilecek uygulamalardır. Öncelikle Türkiye'nin bu alandaki planlamasının kapsayıcı ve ortak kriterler üzerinden yapılmasına ihtiyaç vardır. Zira bu konuda yaşanacak her türlü sorunun yaratacağı tahribat ilgili öğretim kurumuyla sınırlı kalmayacak, ülkenin dışarıdan görünümünü de olumsuz etkileyecektir. Bu sonuç ise Türkiye' de yükseköğretimde uluslararasılaşma stratejisinin ruhuna her bakımdan aykırıdır. Kaldı ki harç tutarları doğrudan devlet bütçesine gelir kaydedildiği için bu tutarların belirlenmesinde kullanılması gereken kriterler acilen belirlenmelidir. Bu tedbire ek olarak kimi üniversitelerde çoğu zaman "bağış" olarak kaydedilen ve bir defaya mahsus alınan ücretlerin alınması engellenmelidir. Eğitimi için çoğu zaman gelirine bakılmaksızın burslandırılan, esasında kendisine ait bir geliri de bulunmayan 
öğrencilerin "bağış" türünde kaydedilen bir ödemeyi gönüllü yapmadıkları herhangi bir izaha gerek olmadan anlaşılabilecek bir durumdur.

\subsubsection{Kayıt Sonrası ve Mezuniyet Dönemi}

Yükseköğretim her şeyden önce nitelikli insan yetiştirme sürecidir. Bu amaçla ciddi yatırımlar gerektirmektedir. Ülkelerin uluslararası öğrenci stratejisinin temel hedeflerinden biri de bu eğitim sürecini başarıyla tamamlayan öğrencilerden en yüksek oranda faydalanmaktır. Fakat Türkiye'de hem kayıt hem de mezuniyet sonrasına dönük çalışmalar oldukça sınırlıdır.

Kayıt sonrasında eğitim öğretim sürecinin iyileştirilmesi adına öğrencilerin memnun olma ve memnuniyetsiz olma ya da başarılı ve başarısız olma sebeplerine dönük yapılan bilimsel saha araştırmaları ya oldukça sınırlıdır ya da hiç yapıımamaktadır. Oysa üniversite, kendi içerisindeki uygun programlar yoluyla bu saha araştırmalarını yaparak sürecin en başından kontrollü bir biçimde yürütülmesini sağlayabileceği gibi öğrenci yeterlilikleri konusunda da ciddi bir malzeme toplamış olur. Öğrencinin kayıtla birlikte neredeyse her anlamda kendi kararına ve kaderine terk edildiği bir sürecin istenilen ölçüde başarılı olması imkânsızdır.

Yetişmiş uluslararası öğrencilerin ülkenin hangi alan ve kurumlarında istihdam edilmeleri gerektiği konusunda gereken çalışmalar yapılmalı, özellikle çok stratejik alanlardaki ihtiyaçlarına dönük sunabilecekleri katkılar değerlendirilmelidir. Bu amaçla yine Türkiye'de çok yaygın olarak yapılmayan mezun öğrencinin istihdam sürecini takip edecek bir programın geliştirilmesine ihtiyaç vardır.

Türkiye'de bir yükseköğretim kurumundan lisans seviyesinde iyi dereceyle mezun olan öğrencilerin eğitimlerine yine Türkiye'de devam etmelerini özendirecek çalışmalar yapılması da önemlidir. Bunun için gerek mezuniyet sonrası 1 yıl olan ikamet süresinde gerekse yüksek lisans ve doktora programlarına başvuru ve kabullerde intiyaca dönük düzenlemeler yapılmalıdır. Türkiye'de bir yükseköğretim kurumundan mezun olan bir öğrencinin sonrasında Türkiye'de kalması için çalışma ve ikamet izni kolaylaştırılmalıdır. Sürekli şikâyet edilen beyin göçü böylelikle tersine çevrilmeli ve öğrencinin mezun olduğu alanla ilgili istihdam süreci oluşturulacak takip programı üzerinden takip edilmelidir.

\subsection{Akademik Alandaki Sorunlara Dönük Çözüm Önerileri}

Uluslararası öğrenci ve ona öğrenim hizmeti sunmayı vadeden ülke arasındaki ilişkinin kurulmasını sağlayan asıl alan akademik alandır. Bürokratik ve sosyolojik süreçler bu alanın verimine dolaylı olarak tesir eden ikincil başlıklardır. Bu alan aynı zamanda kendisinden kaynaklı sorunların en az ve düzeltilmesi en kolay olan olması bakımından da önemlidir. Alanının sınırlı oluşu, bileşenlerin azlığı bu açıdan ciddi bir avantajdır.

\subsubsection{Dil (Türkçe) Hazırık Sorunu}

Türkiye'de dil öğretim meselesi her ne kadar istenilen ölçüde olmasa da ciddiye alınan bir öğretim sürecidir. Eğitim, istihdam ve kariyer noktasında dil öğrenimi neredeyse bir fetiş derecesinde öncelenmekte ve bu alana dönük yatırımlar sürekli olarak desteklenmektedir. Nitekim üniversitelerde yabancı dille verilen programların dil hazırlık süreçleri için yüksekokul düzeyinde bir öğrenim süreci yürütülmektedir. Bu kurumlar materyal, öğretim elemanı, ölçme değerlendirme süreçleri bakımından ciddiye alınan kurumlardır. 
Dil öğreniminin her anlamda teşvik edildiği Türkiye'de, Türkçe programlarda öğrenim görecek uluslararası öğrencilerin Türkçe hazırlık süreci ise oldukça amatör şartlarda sürdürülmektedir. Bu sebeple öğrenci öğrenimini sağııklı bir şekilde sürdürebileceği ve bilgiye erişebileceği dil donanımından uzak kalmaktadır. Bu anlamda Türkçe hazırlık eğitimi veren ve çoğu üniversitede TÖMER olarak bilinen dil öğretim merkezlerinin kurumsal kimliği sorunludur. Bir ülkenin kendi dilinin akademik seviyede öğretilmesi meselesine yaklaşımını da ortaya koyacak bir hususiyete sahip olan bu merkezler hem kimlik olarak hem de yürüttükleri öğretim süreci bakımından farklı diller ile öğretim hizmeti veren programlar için dil hazırlık öğretimi yapan yüksekokullar kadar ciddiye alınmamaktadır. Öncelikle bu kurumsal kimliğin oluşturulması ve akademik seviyede Türkçe öğretiminin bir devlet politikası haline getirilmesine intiyaç vardır.

Türkçenin akademik seviyede öğretilmesi konusunda en büyük sorunlardan biri de ihtiyaca tam anlamıyla cevap verebilecek yazılı, görsel ve işitsel materyalin bulunmayışıdır. Bu sorun yukarıda bahsedilen konunun bir devlet politikası haline gelemeyişi ile doğrudan ilgilidir. Alana kaynaklık eden kitaplar Türkiye'de ikamet eden ve yükseköğrenim görecek bir öğrencinin kayıt yaptırdığı ya da yaptıracağı alana destekleyen bir içerik ve teknikte hazırlanmalıdır. Bu materyallerde hedef kitlenin intiyacı doğru anlaşımalı ve özellikle dört temel dil becerisi aynı derecede kazandırılmalıdır. Sürecin planlamasında mutlaka bir becerinin öncelenmesini gerektiren bir durum varsa yazılı ifade ve okuma becerisi dinleme ve konuşma becerisine göre daha yoğun bir biçimde ele alınmalıdır. Zira dinleme ve konuşmanın Türkiye'de hazırlık eğitimi alan bir öğrenci için gündelik yaşam içerisinde de desteklenip geliştirilmesi mümkündür.

Türkçe hazırlık öğretimi yapan kurumların ortak bir öğretim programının bulunmayışı ve bu alana dönük öğretim elemanı yetiştiren lisans programlarının yetersizliği de bir başka sorun başlı̆̆ıdır. Bu sorunun kesin çözümü ancak uluslararası öğrencilere Türkçe hazırlık eğitimi verecek öğretim elemanlarını yetiştirecek lisans programlarının sayısının artırılması ile mümkündür. Çünkü bu öğretim süreci deneme yanılma ile götürülecek bir öğretim süreci değildir. Alana uygun niteliklere sahip öğretim elemanlarının yetiştirilmesi ile eşzamanlı olarak, alanda hem pratik olarak hizmet veren hem materyal üreten hem de teorik anlamda planlama ile uğraşan tarafların ortak bir öğretim programı hazırlaması gerekmektedir.

Türkçe hazırlık öğrenimi yaklaşık bir yıl sürmektedir. Yükseköğretim için Türkçe dil hazırlık öğrenimi görmek isteyen öğrencinin vize ve ikamet izni alabilmesi için bir yükseköğretim kurumuna kaydının bulunmasının zorunlu tutulması da bir başka sorundur. Çünkü çoğu zaman öğrenci ve ilgili kurum öğrenci için en uygun programı bu dil öğrenim süreci içerisinde yahut sonunda belirleyebilmektedir. Bu zorunluluğun lise diploması, belli bir yaş aralığı ve hazırık eğitiminin süresiyle sınırlandırılması Türkiye'nin en önemli ihraç kalemlerinden biri olan dilinin iyi derecede öğrenilmesini de mümkün kılacaktır. Öğrencinin ülkeye girişi ve ikameti konusundaki bu zorunluluk, bugün için çoğu üniversite tarafından öğrencinin hiç ilgisi olmayan programlara kaydedilmesi ve dil hazırlık sürecinden sonra asıl okumak istediği programa aktarılması yoluyla aşılmaktadır. Hem Türkçenin kıymetinden kaybettiren hem de kurumlar arasında bir güven sorununa yol açan bu uygulama Türkçe lehine değiştirilmeli ve Türkçenin hazırlık seviyesinde öğrenimi de eğitim vizesi ve ikamet izni için yeterli olmalıdır.

Dil öğretimi konusunda son söz olarak, yabancı dil öğretimi terminolojisindeki "yabancı" kelimesinin, metaforik söylemleri daima gündeminde ve canlı tutan yeni nesillerin durumu göz önüne alınarak, mutlaka mevzuattan çıkartılması gerekmektedir. Çünkü, yabancı kavramı beraberinde doğal olarak metaforik anlamda ötelemeyi ve ilgilenmemeyi çağrıştırmaktadır. 


\subsection{2. Öğretim Elemanı Sorunu}

Uluslararası öğrenci ile doğrudan ve uzun süreli etkileşim içerisinde olanlar daha çok öğretim elemanlarıdır. Öğretim elemanları uluslararası öğrenci hareketliliğindeki cazibenin başlaması ve süreklilik göstermesi anlamında temel aktördür. Çünkü öğrencinin kendi ülkesinden ayrılarak bir başka ülkeye gitmesindeki temel motivasyon yükseköğrenimini tamamlamaktır.

Bugün için Türkiye'de öğretim faaliyetleri yanında inceleme ve araştırma faaliyetlerini de yürütmeye çalışan öğretim elemanlarının sayısı istenilen seviyede değildir. Öğrenci başına düşen öğretim elemanı sayısının artması hem öğrencinin öğrenme kalitesini hem de öğretim elemanının öğretim süreci dışındaki sorumluluklarını yerine getirmesini kolaylaştıracaktır. Bu sorun konusunda ilgili kurumların gerekli çalışmaları yaptıkları ve son yıllarda yükseköğretim kurumlarındaki öğretim elemanı sayısının arttığı gözlenmektedir. Fakat öğretim elemanı sayısı ile birlikte yükseköğretim kurumunun sayısının da artması kurumların ve programların öğretim elemanı ihtiyacının tam olarak karşılanmasını olumsuz yönde etkilemektedir. Bu anlamda öğretim elemanı sayısından etkin bir biçimde faydalanabilmek için yükseköğretim kurumları arasında ciddi bir iş birliği gerçekleştirilmelidir.

Yükseköğretimde özellikle uluslararası öğrenciler bağlamında öğretim elemanlarının yeterliliklerinin artırımasına dönük çalışmaların yapılmasına ihtiyaç vardır. Bu konuda diğer ülkelerdeki yükseköğretim kurumlarıyla öğretim elemanı değişim programlarını yaygın hale getirmek öncelikli çözüm yollarından birisi olabilir. Böylelikle öğretim elemanı zihin hazırlı̆ı̆ ve teknik yeterlilik anlamında kendisini geliştirme imkânı bulurken bu sürenin değişim programı kapsamında gelen misafir öğretim elemanı ile yürütülmesi mümkün olacaktır. Üniversitelerde ağılıklı olarak yaşanan öğretim elemanının programın verildiği dili yeterli derecede bilmemesinden kaynaklı sorunların çözümünde bu değişim programı etkili olacaktır.

Ayrıca öğretim elemanının yükseköğretimde uluslarasılaşma perspektifine uygun hareket edebilmesi için bu sürece ilişkin dinamik olarak bilgilendirileceği etkinlikler gerçekleştirilmelidir. Kurum yöneticileri ve öğretim elemanı arasında sağlıklı bir iletişim olmalı ve süreçte yaşanacak sorunların öğretim elemanının motivasyonunu olumsuz bir şekilde etkimesinin önü alınmalıdır.

Dil öğretimi sürecinde uluslararası öğretim elemanı istihdamı önemli bir kaynak olarak değerlendirilmelidir. Özellikle yükseköğrenimini Türkiye'de tamamlayan uluslararası öğrencilerden uygun olanların öğretim elemanı olarak istihdamı, uyum sorunu da yaşanmayacağı için uluslararası öğrenciler kadar yerli öğretim elemanlarına ve yerli öğrencilere ciddi katkılar sağlayacaktır.

Öğretim elemanlarının üniversitede ve özellikle kendi programında öğrenim gören öğrencilerle ilgili bir önbilgiye sahip olması sağlanmalıdır. Karşılıkı hassasiyetler konusunda taraflar önceden bilgilendirilmeli ve önyargıların oluşması engellenmelidir. Öğretim elemanlarının bilgilendirilmesi, uluslararası öğrencilerin başvuru, kabul ve kayıt sürecini yürüten uluslararası öğrenci koordinatörlüğü üzerinden gerçekleştirilmelidir. Böylelikle bu birimin öğrencilerin bilgilerini sağlıklı bir biçimde işlemesi ve içselleştirmesi sağlanmalıdır.

\subsubsection{Ortak Zorunlu Dersler ve Ölçme Değerlendirme Sorunu}

Yükseköğretimin ilk sınıfında ortak zorunlu dersler olarak müfredatta yer alan Türk Dili, Atatürk İlkeleri ve İnkılap Tarihi derslerinin planlanması ve adlandırılması uluslararası öğrencilerin durumu göz önünde bulundurularak yeniden yapılmalıdır. Türk Dili ders içeriğinin Türkçe dil hazırlık eğitimini esas alacak şekilde ve yerli öğrencilerden farklı olarak verilmesi ve değerlendirilmesi gerekmektedir. Atatürk İlkeleri ve İnkılap Tarihi dersinin de yeni bir başıık ve ülkenin yine yakın tarihini ve bugününü özet bir şekilde verecek bir planlama ile anlatılması da zaruridir. Çünkü bu ders sadece yakın tarih değil geçmiş 
dönemlere referanslarla anlaşılabilecek derinlikli ve çok yönlü bir dönemi kapsamaktadır. Oysa uluslararası öğrencinin yerli öğrenciden farklı olarak bu dönemin üzerine inşa edildiği geçmiş dönemlerle ilgili bir kazanımı yoktur. Bu iki dersin içeriğinin ihtiyaç ve rasyonalite esaslı yeniden planlanması sayesinde hem fırsat eşitliği sağlanmış hem de bu derslere işlerlik kazandırılmış olacaktır.

Ölçme ve değerlendirme konusunda uluslararası öğrenciye has sorunlar daha çok önyargı, ideolojik kabuller ve ayrımcı bakış açısından kaynaklandığı için bir önceki maddede anılan çözüm yolları bu başlı̆ı̆n çözümünde de etkili olacaktır. Uluslararası deneyimi olmayan, bilgi eksikliği olan ve önyargıları bulunan öğretim elemanlarının değişim programları, etkin ve yeterli bilgilendirmeler yoluyla sağlıklı bir ölçme ve değerlendirme yapması sağlanabilir. Ayrıca ölçme ve değerlendirme süreçleri öğretim elemanlarından bağımsız bir süreç olarak da yürütülebilir. İlkeleri önceden belirlenmiş, soruları kadar cevap ve değerlendirmelerin de ulaşılabilir olduğu şeffaf bir ölçme ve değerlendirme sistemi sadece uluslararası öğrenciler için değil yerli öğrenciler için de olumlu bir adım olur.

\subsection{Sosyolojik Sorunlara Dönük Çözüm Önerileri}

Uluslararası öğrencinin yükseköğrenim hayatını sürdürdüğü çevreyle iletişimi akademik başarısını doğrudan etkiler. Hem sınıf ortamındaki sosyal ilişkileri hem de günlük yaşamında kurduğu toplumsal ilişkilerin kalitesi Türkiye'de yaşanacak uluslararası öğrenci hareketliliğinin temel belirleyicilerindendir. Türkiye'yi tercih eden öğrencilerin dağılımına bakıldığında bu durum net olarak görülmektedir. Kültür şokunun en az yaşanacağı ve ortaklıkların ortalamanın üzerinde olduğu bölgelerden gelen uluslararası öğrencilerin Türkiye' de yaşadığı sorunlar kronik sorunlar değildir. Yaygın bir özellik göstermeyen bu sorunların kaynağı en başında söylendiği üzere sağılılı bir planlama ve bilgi eksikliğidir.

\subsubsection{Barınma Sorunu}

Türkiye'nin uluslararası öğrenci hareketliliğini öğrenci sayıları üzerinden değerlendirme alışkanlığından, öğrencilerin memnuniyeti ve başarısı üzerinden değerlendireceği bir sürece geçilmesi gerekmektedir. Öğrencinin başvurusu, kabulü ve kayıt sürecini tamamladıktan sonra kendisini hiçbir şeyden sorumlu saymayan bir bakış sorunludur. Bu sebeple kayıt sonrası sürecinin, öğrenci henüz kayıt almadan hatta başvuru yapmadan planlanması şarttır. Öğrencinin barınma ihtiyacı da önceden planlanması gereken konulardan biridir. En başından beri söylendiği üzere yükseköğretim kurumu hem Kredi ve Yurtlar Kurumu hem de özel yurtlarla koordineli bir biçimde çalışmalı ve öğrenci kayıt sonrasında kalacak yer sorunu yaşamamalıdır. Çünkü her ne kadar istekli olursa olsun bir başka ülkeye gelmenin stresiyle baş etmeye çalışan genç öğrencinin işlerinin kolay, hızlı ve iyi bir şekilde yürütülüp tamamlanması onun çevresine uyumunu da kolaylaştıracaktır.

Öğrencilerin yurt işletmecilerinin insafına terk edilmemesi için, Kredi Yurtlar Kurumunun uluslararası öğrenciye yönelik bugün uyguladığı kontenjan miktarını duruma göre esnetecek bir mevzuata sahip olması gerekmektedir. Öğrencinin konaklamadan kaynaklı problemlerinde üniversite öğrencinin yanında olmalı ve onun sorununun çözümüne katkı sağlamalıdır. En azından barınma konusunda yaygın olarak yaşanan sorun başlıkları saha araştırmaları yoluyla tespit edilmeli ve bunlara dönük çözüm önerileri geliştirilmelidir. Öğrencilerin barınma ihtiyacı aynı zamanda yemek, temizlik, derse hazırlık ve dinlenme ihtiyaçlarını da içerdiğinden hiçbir öğrencinin daha azına zorlanmasına ya da yüksek maliyetlere rağmen bu ihtiyaçların karşılanmamasına izin vermeyecek bir kontrol sistemini geliştirmek üzere çalışılmalıdır.

Diğer taraftan belli sayıda öğrencinin kiralık ev, süit oda gibi mekânlarda kalma isteği sosyal ve kültürel farklııklar dolayısıyla yönetilmesi zor bir süreç haline gelmektedir. Öğrenciler zorlukla kiralık 
ev bulabilmekte, kendilerinden oldukça yüksek kira bedelleri çoğu zaman peşin istenmekte, evin eksikleri konusunda ise ev sahibine düşen yükümlülüklerden kaçınılmaktadır. Öğrenciler yaşadıkları sorunlarla ilgili olarak ise diğer pek çok konuda olduğu gibi ya muhatap bulmakta zorlanmakta ya da gerekli muhataplara hiç ulaşamamaktadırlar. Özellikle barınma konusunda yaşadıkları sorunlar uluslararası öğrencilerin akademik başarıları kadar sosyokültürel uyum süreçlerini de olumsuz etkilemektedir.

\subsubsection{Toplumsal Ortama Uyum Sorunu}

Uluslararası öğrencilerin toplumsal ortama uyumunu sağlamak onların yükseköğretimde başarılı olmasını sağladığı kadar kendi ülkesinde Türkiye'nin gönüllü kültür elçisi olmasını da sağlayacaktır. Bu anlamda öğrencinin geldiği bu yeni ülkenin dili, dini ve diğer kültür başlıklarını yakından tanıyacağı etkinliklere katılımı sağlanmalıdır. Bu anlamda üniversitelerdeki Sürekli Eğitim Merkezleri aktif olarak kullanılmalıdır. Eğlenme biçimlerinden, beslenme şekillerine varıncaya kadar hemen her konuda talebe ve ihtiyaca göre kurslar açılmalı ve öğrencilerin bu kurslara katılımı özendirilmelidir. Talebin kendiliğinden oluşması veya ihtiyacını öğrencinin kendisinin fark etmesi beklenmeksizin gerekli araştırmalar ve yönlendirmeler yapılarak öğrenci bu kurslar sayesinde kısa sürede kazanılmalıdır. Gerekirse gönüllü öğreticiler marifetiyle yöreye ve ülkeye ait güzelliklerin ve hassasiyetlerin aktarılması sağlanmalıdır.

Toplumsal uyum süreci tek taraflı bir süreç olmadığı için bugüne kadar üzerinde pek değerlendirme yapılmayan yerli öğrenciler ve yöre insanının da uluslararası öğrenci konusunda bilgilendirilmesi önemlidir. Öğrencilerin geldikleri ülkelere, inandıkları dinlere, giydikleri kıyafetlere, yedikleri yiyeceklere ve eğlenme biçimlerine karşı bilgisizlikten kaynaklı önyargıları yıkacak görsel, yazılı ve sözlü bilgilendirmeler yapılmalıdır. Yükseköğretim kurumunun dijital imkanları ve sosyal medya platformları bu konuda etkin olarak çalışmalıdır. Bu çalışmalar yapılırken yerli öğrencinin kendisini değersiz hissedebileceği aşııııılardan kaçınılmalıdır. Toplumun, yerli öğrencilerin ve uluslararası öğrencilerin ihtiyaç, beklenti ve sorunlarını tespit etmek için belirli aralıklarla anket uygulamaları, soru cevaplı toplantılar ve farklı araştırmalar yapılmalıdır. Bu çalışmalardan elde edilen sonuçlar ciddiyetle değerlendirilmeli ve çözümüne dönük yeni arayışlara girilmelidir.

\section{SONUÇ}

Uluslararası öğrenci hareketliliği tarih boyunca var olmakla birlikte bugün için ülkeler açısından hem ciddi bir ekonomik girdi hem siyasi bir imkân hem de kültür ihracı için bir fırsat olarak değerlendirilmektedir. Bu üç temel amacın etkisi ilgili ülkenin bu hareketliliğe bakışına bağlı olarak değişmektedir. Kimi ülkelerde bu hareketlilik daha çok bir ekonomik girdi olarak değerlendirilirken kimi ülkeler öğrencileri siyasi nüfuzu için bir aracı olarak değerlendirmektedir. Kimi ülkelerde de uluslararası öğrenci hareketliliği ağırlıkı olarak kültür aktarımı için bir araç olarak değerlendirilmektedir.

Rekabet şartlarının her geçen gün ağırlaştığı uluslararası öğrenci hareketliliğinde Türkiye de bugün için önemli bir noktada bulunmaktadır. Özellikle yükseköğretim seviyesinde uluslararası öğrenci kabul etmeyi bir strateji olarak belirleyen Türkiye, sürecin henüz başında olunduğundan imkânlar ve ilkeler konusunda sorunlar yaşanmaktadır. Öğrenci hareketliliğini üç temel amacın her birinde dengeli bir biçimde kendisine doğru yönlendirme çabasındaki Türkiye'nin özellikle tanıtım ve danışmanlık alanında yaşadığı sorunların çözülmesi konusunda kısa vadede başarılı olması mümkün görünmektedir. Hem yerleşik devlet tecrübesi hem de dışarıda her geçen gün artan popülaritesi sayesinde Türkiye uluslararası öğrenciye ulaşmada ve yükseköğrenim için bir cazibe merkezi olmada önemli adımlar atmaktadır. Türkiye bu ivme ile kısa zamanda uluslararası öğrenci hareketliliği konusunda bir 
uluslararası merkez olma potansiyeline sahiptir. Bu potansiyeli gerçekleştirmede en önemli sorumluluk, projenin önemli paydaşı olan kurumsal bürokrasiye düşmektedir. Bürokraside görev alan fertlerin bilgi, tecrübe ve samimiyeti bu potansiyeli, hayalin ötesinde gerçeğe dönüştürmede en önemli çıpalardır.

\section{Kaynakça}

Çetinsaya, G. (2014). Büyüme, Kalite, Uluslararasılaşma: Türkiye Yükseköğretimi İçin Bir Yol Haritası. Eskişehir: Yükseköğretim Kurulu Yayınları.

Demirhan, K. (2017). Ulusal Alanyazında Uluslararası Öğrenciler ve Uluslararası Öğrencileri Siyasal Açıdan Düşünmek. Uluslararası Yönetim İktisat ve İşletme Dergisi, C. 13, S. 13, s. 547 - 562.

Er, O., Biçer, N., \& Bozkırlı, K. Ç. (2012). Yabancılara Türkçe Öğretiminde Karşılaşılan Sorunların İlgili Alan Yazını Işığında Değerlendirilmesi. Uluslararası TEKE Dergisi, C. 1, S. 2, s. 51-69,

Ercan, M. S. (2012). Öğrencilerin Uyum Sorunlarının İncelenmesi ve Bu Sorunların Çözümüne Yönelik Beklentilerin Araştırılması. Uzmanlık Tezi. T.C. Başbakanlık Yurtdışı Türkler ve Akraba Topluluklar Başkanlığı, Ankara.

Geçkil, T., \& Alagöz, S. B. (2017). Yabancı Uyruklu Üniversite Öğrencilerinin Sorunlarının İncelenmesi: Konya illi Örneği. Anadolu Hemşirelik ve Sağlık Bilimleri Dergisi, C. 20, S. 4, s. 279-285.

Köylü, M. (2001). O.M.Ü. Ilahiyat Fakültesine Devam Eden Yabancı Uyruklu Öğrencilerin Fakülte Hakkındaki Düşünce, Sorun ve Beklentileri. Ondokuz Mayıs Üniversitesi İlahiyat Fakültesi Dergisi, Cilt: 12, Sayı: 12-13, s. 131-153.

Özoğlu, M., Gür, B. S., \& Coşkun, í. (2012). Küresel Eğilimler Işığında Türkiye'de Uluslararası Öğrenciler. Ankara: SETA Yayınları.

Selvitopu, A. (2016). Türk Yükseköğretiminde Uluslararasılaşma Stratejileri: Süreç Yaklaşımı Çerçevesinde Nitel Bir İnceleme. Doktora Tezi. Eskişehir Osmangazi Üniversitesi Eğitim Bilimleri Enstitüsü, Eskişehir.

Uluslararası Öğrenci Sağlık Sigortası, (2021). http://www.sgk.gov.tr/wps/portal/sgk/tr/emekli/sikca_sorulan_sorular/gss_saglik_aktivasyon. Erişim tarihi: 10.02.2021.

UNESCO (2018). http://uis.unesco.org/en/uis-student-flow, Global Flow of Tertiary-Level Students. Erişim tarihi: 10.01.2021.

Yabancılar ve Uluslararası Koruma Kanununun Uygulanmasına illişkin Yönetmelik. (2016). T. C. Resmî Gazete (29656, 17 Mart 2016).

YÖK (2020). https://www.yok.gov.tr/Sayfalar/Haberler/2020/hedef-odakli-uluslararasilasma.aspx. Hedef Odaklı Uluslararasılaşma. Erişim Tarihi: 03.02. 2021.

YÖK (2017). Yükseköğretimde Uluslararasılaşma Strateji Belgesi 2018-2022. 